\title{
Ego Defense Mechanisms in Aesop's Fables
}

\author{
Byung-Wook Lee \\ Eumseong Somang Hospital, Eumseong, Korea
}

이솝 우화를 통해 본 자아 방어기제

이 병 욱

음성소망병원

Aesop was a famous fable and story-teller in ancient Greece, and his fables are still taught as moral lessons today. He is said to have lived as a slave in Samos around 550 B.C. Unfortunately, he met with a violent death at the hands of the inhabitants of Delphi, but the precise and/or accurate cause of his death remains unknown. Aesop's slave status in ancient Greece notwithstanding, he had a keen powers of observation, sensitivity and the linguistic and intellectual ability to convey what he knew in terms of pertinent social criticism. We surmise that this ability was developed from his hard life experience and fine-tuned by his intellect, but his moral sense seemed to have been very conservative. I would, in this regard, like to emphasize the many and various ego defense mechanisms incorporated into his famous fables. As a matter of course, Aesop knew nothing about the psychoanalytic concepts (including entities such as the unconscious and ego defense mechanisms), but we are able to empathize with the tales conveyed by his fables because many of the essential, underlying messages in his stories are every bit as applicable to life today as they were in ancient Greece. Many of Aesop's fables are so analogous to our present and often contradictory life experience, it sometimes seems as if each of his fables he neatly and correctly tweezed a thorn out of the finger of humanity. We have (anecdotally) confirm that human ego defense mechanisms have been in full operation without change for several thousands of years.

Psychoanalysis 2017;28(4):83-95

KEY WORDS: Aesop · Fables · Defense mechanism.

Received: September 20, 2017 Revised: October 13, 2017 Accepted: October 16, 2017

Address for correspondence: Byung-Wook Lee, MD

Eumseong Somang Hospital, 518 Ilsaeng-ro, Saenggeuk-myun, Eumseong 27621, Korea

Tel: +82-43-878-4111, Fax: +82-43-878-3062, E-mail: hanvitwooklee@naver.com

\section{서 론}

이솝의 이야기는 가장 오랜 세월 동안 전 세계 일반대중 들로부터 널리 사랑받아온 우화일 것이다. 그의 그리스 명은 아이소포스로 알려져 있는데, 헤로도토스에 따르면 그는 기 원전 6세기경 사람으로 델포이에서 살해되었다고 전해지지 만 그 진위 여부는 알 길이 없다. 검고 추한 외모에 안짱다리 로 알려진 용모 역시 사실 여부를 가릴 수가 없다. 고대 그리 스가 낳은 위대한 인물 가운데 소크라테스와 플라톤, 아리스 토텔레스, 소포클레스, 히포크라테스, 호메로스, 알렉산더 대왕의 명성에 결코 뒤지지 않게 유명한 인물이지만, 다른

This is an Open Access article distributed under the terms of the Creative Commons Attribution Non-Commercial License (http://creativecommons.org/licenses/by-nc/4.0) which permits unrestricted non-commercial use, distribution, and reproduction in any medium, provided the original work is properly cited.
점이 있다면 비천한 노예 출신이라는 것이다. 그는 낮은 신 분에서 겪었던 인생의 온갖 희비애환을 날카로운 직관력과 상상력으로 시대적, 문화적 차이를 뛰어넘는 만고의 진리를 가르치고 설파했다(Keller와 Keating 1993). 영국은 셰익스 피어를 자랑하지만 그의 작품배경은 대부분 귀족층을 상대 로 한 것이며, 힘없는 민중들의 삶은 제대로 반영되어 있지 못했다고 할 수 있다. 반면 이솝은 힘없고 가난한 민중들의 삶에 초점을 맞췄다는 점이 위대한 휴머니즘 작가의 선각자 로 칭할 만하다. 고금동서를 막론하고 오랜 세월 사랑받은 이솝 이야기의 비밀은 바로 그러한 서민의 애환을 반영하며 삶의 지혜를 전해준 데 있을 것이다.

뿐만 아니라 다양한 소재를 통하여 온갖 인간 군상들이 펼치는 희로애락과 어리석음, 시기와 모함, 성공과 실패담 등을 매우 희화적인 수법으로 보여주고 있다. 이는 독자들을 즐겁게 해주며 동시에 이야기 속의 동물들과의 만남을 통해 
서 인간의 어리석은 행동 이면에 놓인 다양한 동기와 방어 유형들을 재경험하며 반성하게 되는 교훈도 얻는다. 따라서 이솝의 우화를 통해 우리는 건강하고 올바른 삶의 정신이 무엇인지 새삼스레 깨달을 수 있다. 이런 면에서 이솝 우화 는 단순한 어린이용 담론이 아니라 통찰적인 효과를 지닌 지혜의 보고임을 깨닫는다. 이에 저자는 이솝 우화에 나타난 다양한 자아 방어기제를 살펴봄으로써 건강한 자아의 확립 에 기여한 이솝의 숨은 공헌을 재평가하고자 한다.

\section{본 론}

\section{이솝 이야기의 교훈}

이솝은 기원전 620 년경에 태어나 기원전 560년에 사망한 고대 그리스의 우화작가다. 그에 관해서는 노예 신분이라는 사실만 알려져 있을 뿐 정확한 출생지조차 알려진 바가 없다. 다만 그의 이름이 이솝이라는 점에서 에티오피아에서 건너온 노예가 아니었을까 주장하는 사람도 있다(Lobban 2004). 더 욱이 그가 즐겨 비유한 동물들이 사자, 낙타, 원숭이 등 주로 아프리카에 서식하는 야생동물이라는 점에서 매우 그럴듯 하게 들리기도 한다. 그러나 출신지는 중요한 문제는 아니며 고대시기에 이미 이솝과 같은 천재적인 이야기꾼이 존재했 다는 사실 자체가 놀라울 뿐이다. 그가 활동하던 시기는 페 르시아 왕국, 바빌로니아 왕국, 카르타고 등이 융성하던 때 로 당시 중국은 춘추전국시대요, 우리나라는 고조선 시대로 철기문화가 막 시작되던 무렵이었으니 이솝의 활동 시기가 얼마나 오래 전의 일인지 알 수 있다. 그는 석가, 공자, 소크 라테스, 예수 등 4대 성인이 태어나기 훨씬 이전의 인물이라 는 점에서 그리고 인간의 희로애락과 심리적 갈등 상황에 매우 민감한 감수성의 소유자였다는 점에서 그의 가치가 더 욱 빛을 발하는 것이다. 호메로스가 귀족 중심의 대서사시를 썼다면 이솝은 그 자신이 노예 출신답게 매우 서민적인 이야 기들을 남겼다. 또한 호메로스가 웅대한 전쟁을 주로 다루었 다면 이솝은 노동의 소중함을 강조하고 일반 대중들이 이해 하기 쉬운 교훈적인 내용의 메시지를 전달하는 데 주력했다.

그러나 윤리적 차원뿐 아니라 이솝은 힘 있는 자, 가진 자, 교만하고 위선적인 자들에 대해서도 비판을 가한다. 다만 그 는 매우 우회적인 방식을 취할 뿐이다. 그가 던지는 교훈은 매우 단순한 형식을 취하지만 그 내용은 생각처럼 그렇게 단순치만은 않다. 이솝 이야기의 주제는 대체로 삶의 지혜와 용기, 은혜와 배은망덕, 비굴함과 자만심, 충성과 반항, 근면 과 나태, 정직과 거짓, 오만과 겸손, 만용과 순리, 욕심과 청 빈, 선과 악, 부와 가난, 주인과 노예 등 매우 광범위한 내용 을 다루고 있다.
무지하고 비천한 노예 출신치고 이솝의 초자아는 상당히 완고한 편이다. 그는 이드의 욕망 충족에 반대하고 거의 청 교도적 생활 방식에 가까운 경건한 삶의 태도를 요구한다. 디 오게네스적 자유방임주의와 에피쿠로스적 쾌락 지상주의는 이솝의 생활철학에 배치된다. 그렇다고 소포클레스와 같은 어둡고 음울한 분위기도 아니다. 오히려 천진난만할 정도로 실수와 실패를 반복하는 동물들의 어리석음을 희화적으로 보여줌으로써 어리석은 자들에 대한 따스한 동정과 이해뿐 아니라, 그러한 무지와 어리석음을 깨닫고 새롭게 변할 수 있는 세상을 꿈껐다는 점에서 사실은 순진무구한 낙천가였 을 것이라는 점도 추측케 한다. 그러나 세상을 변화시키는 힘은 무책임한 낙관론이 아니라 고뇌하는 회의론에서 나온 다는 말이 있듯이 이솝의 이야기가 세상을 변화시키기에는 문제 해결 방식이 단순하고 지나치게 간단명료하며 낙천적 이기 때문에 그 자체가 한계를 갖는 것인지 모르겠다. 그럼 에도 불구하고 이솝 이야기의 강점은 매우 현실적인 차원에 서 인간의 탐욕과 어리석음을 꾸짖으며 문명인으로서 지녀 야할 올바른 삶의 태도를 제시했다는 점이다.

\section{이솝과 동물들}

이솝 이야기에 나오는 주인공들은 거의 대부분이 동물들 이다. 동물들이 보여주는 온갖 어리석음은 사실 인간의 어리 석음을 의인화한 것이다. 주로 등장하는 동물은 여우와 늑대, 개미, 비둘기, 제비, 닭, 나귀와 당나귀, 곰, 사자와 낙타, 원숭 이, 토끼와 거북이, 개구리와 두루미, 까마귀, 양, 염소, 쥐 등 이다. 이솝은 동물의 특성에 대한 면밀한 관찰을 토대로 인간 들의 어리석음을 동물의 언행에 빗대어 이야기로 꾸몄다. 이 솝이 동물을 자주 등장시킨 것은 동물에 대한 사랑이 각별해 서라기보다는 그 편이 더욱 신변에 안전했기 때문이었다. 사 람을 주인공으로 했을 경우, 혹시라도 왕과 신하, 주인과 노 예의 관계에서 비롯되는 갈등이나 마찰, 또는 직접적인 힐난 등으로 비쳐질까 우려했기 때문이다. 이처럼 인간이 아닌 동 물의 이야기인 듯이 꾸미는 전략은 화자 및 독자 모두에게 안전장치를 미리 제공하는 것이어서 매우 효율적인 방식이 라 할 수 있으며, 이미 그것은 적절한 방어기제를 동원하고 있는 것이다. 동물의 왕 사자는 양처럼 온순하고 연약한 동 물들을 괴롭히고 잡아먹는 존재로 자주 등장하는데 이는 막 강한 권력을 행사하는 왕이나 주인을 나타낸다. 반면에 여우 와 늑대는 항상 나쁜 짐승으로만 나오는 것이 아니다. 여우 는 꾀가 많은 짐승으로 좋게 말하면 지혜를 상징하는 동물 로도 자주 나온다. 전설이나 민담의 측면에서 본다면 서양에 는 늑대가 주역이고 동양은 여우가 주역인 경우가 흔하다.

특히 인간으로 변신한 짐승 이야기일 경우에는 서양은 주 
로 늑대인간에 관한 내용이 주종을 이루며, 동양은 여우가 사람으로 변신하여 남성들을 홀린다는 내용이 주를 이룬다. 당나귀는 힘은 좋지만 어리석은 동물로 자주 등장한다. 일만 죽도록 하는 어리석은 노예를 상징하는 대표적인 동물로 등 장한다는 점에서 당나귀는 이솝 자신의 고달픈 신세를 반영 하는 상징적 존재다. 당나귀를 구박하고 비웃는 주인의 비정 한 모습은 이솝 자신이 직접적으로 털어놓을 수 없는 주인 에 대한 불만을 우회적으로 드러낸다.

앞서 언급했듯이 이솝 우화에 등장하는 동물들 가운데 사 자, 낙타, 원숭이, 코끼리 등 아프리카에 야생하는 짐승들이 나타나는 것으로 보아 이솝이 아프리카에서 건너온 흑인 노 예 출신이었을 것으로 추정하는 사람도 있다. 그런 동물들은 고대 그리스에 서식하지 않았기 때문이다. 물론 고대 그리스 문명은 지중해를 석권함으로써 다양한 문명세계와 문물을 교환하기도 했지만, 헬레니즘 문명의 세계화를 이룩했던 알 렉산더 대왕의 동방원정이 시작된 것은 이솝이 생존했던 시 기보다 300년이나 후에 이루어진 일이었다.

그러나 그 시기 이전에도 북아프리카와의 교류는 있었을 것이기 때문에 이들 동물에 관한 지식은 충분히 알려져 있었 을 것이다. 단적인 예로 기원전 1500 년을 전후하여 크레타 섬을 중심으로 이룩된 미노스 및 미케네 문명의 유적을 보더 라도 그 시기에 이미 사자 문양의 조각상이 존재했기 때문이 다. 다만 아프리카를 제외한 전 세계 어디에나 존재했던 소, 말, 돼지 등 문명사회에서 가장 흔히 접하는 동물들이 이솝 우화에 거의 등장하지 않은 점은 그의 아프리카 출신 배경 설에 더욱 신빙성을 더하는 일이다.

\section{자아 방어기제}

방어라는 용어가 처음 사용된 것은 프로이트가 정신분석 을 공식적으로 표명하기 이전에 이미 그의 초기 논문에서 발견된다(Freud 1894). 그러나 당시 주된 관심은 리비도 연 구에 집중되어서 상당 기간 방어기제에는 관심을 기울이지 않다가 후기에 자아 기능에 주목하게 되면서 방어기제들에 도 관심을 기울이게 되었다(Freud 1925). 따라서 구조이론을 통하여 자아심리학의 토대가 마련된 것이라면 방어기제야말 로 자아의 중요한 기능 가운데 하나로 떠오르게 된 것이다. 그 결과 방어분석 또한 치료과정에서 중요한 기법 가운데 하 나로 자리 잡게 되었다. 프로이트는 주된 방어기제로 억압을 강조하였지만, 안나 프로이트를 위시한 그의 후계자들은 더 욱 다양한 기제들을 세분화시키고 다듬어 나갔다. 방어기제 에 대한 과도한 강조는 그 후 인간의 자아를 한낱 방어의 집 합체로 취급한다는 비판을 받기에 이르기도 했지만, 그 비판 은 문제의 본질을 호도시키는 과장된 논리의 비약에 지나지
않는다. 공격과 방어라는 용어 자체에서 풍기는 군사적인 뉘 앙스도 매우 호전적인 이미지를 남긴다. 그럼에도 불구하고 방어기제의 개념은 우리 자신의 심리적 현상을 설명하는 데 있어서 아주 유용한 장치다. 꿈 분석에 치중했던 프로이트와 는 달리 오늘날의 정신분석에서는 방어 및 전이분석을 임상 적으로 매우 중요한 과정으로 간주하고 있다. 정신의학 임상 에서도 방어기제의 이해는 환자의 심리를 이해하고 치료하 는 데 있어서 매우 중요한 요인으로 인식한다(Lee 1997). 놀 라운 점은 고대인이었던 이솝의 이야기들에서 이미 수많은 방어기제의 동원이 내포되어 있다는 사실이다. 방어기제의 개념조차 존재하지 않았던 그 시기에 이미 이솝은 온갖 시행 착오를 거듭하는 인간의 불합리한 모순과 어리석은 행동들 을 통해 드러난 다양한 방어적 태도에 주목하고 그 자신의 예리한 시각으로 관찰하고 있다.

\section{억압(Repression)}

억압은 불안에 대한 일차적 방어기제이다. 일차적이라 함 은 가장 기본적인 방어기제라는 의미로 일단 억압에 실패하 게 되면 이차적으로 다른 다양한 기제들이 동원되기 때문이 다. 또한 억압이 많을수록 편견이나 선입견에 사로잡히기 쉽 다(Lee 2003b). 「북풍과 태양」에서 북풍은 강제로 나그네의 옷을 벗기려 하지만 세차게 불어댈수록 나그네는 더욱 옷깃 을 여미는 행동을 보인 반면에, 태양은 서서히 햇살을 쪼이 면서 더위를 느낀 나그네가 스스로 옷을 벗게 만들어 시합 에서 이긴다. 여기서 나그네가 입고 있는 옷은 억압의 옷이 다. 충동이나 자극이 강할수록 억압은 더욱 강해진다.

그러한 억압의 옷을 벗게 만드는 것은 강요로 되지 않으며 단번에 이루어지는 것도 아니다. 그것은 서서히 단계적으로 자연스런 이해의 과정을 통하여 이루어지기 마련이다. Reich (1933)는 성격 무장(character armor)이라는 용어를 사용하였 는데, 마치 갑옷처럼 우리 자신은 내면적 진실을 위장하기 위 해 겹겹이 억압의 갑옷을 걸치고 살아가기 마련이다. 이러한 갑옷이 무거울수록 인간은 더욱 신경증적인 경향이 두드러진 다. 정신분석의 일차적인 목표는 중무장된 억압의 갑옷을 서 서히 벗겨나감으로써 심리적 평형을 이루도록 도모하는 과정 이라고 볼 수 있다. 분석가는 북풍처럼 무리한 요구나 강요를 가하지 않으면서 태양처럼 서두르지 않고 환자 스스로가 자 신의 무장을 해제하도록 치료적 분위기를 이끈다.

그러나 실제로 많은 환자들은 치료를 통해 자신의 신경증 적 고통을 직면하고 돌파해 나가기보다는 퇴행적인 신경증 상태에 그대로 안주하려는 경향을 보이기 쉽다. 퇴행을 일종 의 현실도피적인 방어라고 볼 때, 자신의 병을 과소평가하려 는 억압의 방식은 머리를 모래에 처박고 문제가 해결되었다 
고 믿는 타조의 처세술과 비슷하다 해서 프로이트는 그것을 타조 기제라 불렀다(Freud 1914). 하지만 엄밀히 말하자면, 타조 기제는 현실을 부정할 뿐만 아니라 스스로 안전하다고 자신을 달래는 모습이기 때문에 부정과 합리화를 동시에 동 원한 것이라 할 수 있다.

\section{퇴행(Regression)}

퇴행은 심리적 좌절을 겪게 되는 상황에서 이를 회피하기 위해 보다 유치한 과거의 수준으로 후퇴하는 과정이다. 동생 이 태어난 후 갑자기 오줌을 싸기 시작하는 아이의 경우, 입 원한 환자가 어린애처럼 응석과 투정을 부리는 경우 등도 일 시적인 퇴행을 보인 것이다. 프로이트의 퇴행 개념은 사실상 다윈의 진화론 개념에 배치되는 것이다. 그러나 엄연히 인간 은 심리적 퇴행 현상을 도처에서 보이고 있다. 또한 모든 퇴 행이 병리적인 것은 아니라는 사실도 잘 알고 있다. 적절한 정상적 퇴행이 요구되는 상황도 실제로 존재한다. 그런 점에 서 모든 퇴행이 잘못된 것은 아니다.

「아라비아 상인과 낙타」의 이야기는 그러한 퇴행 과정을 잘 보여준다. 길을 가던 아라비아 상인이 밤이 되자 사막에 천막을 치고 잠을 청했다. 그런데 밖에 있던 낙타가 천막 안 으로 고개를 들이밀며 날씨가 추우니 코만 살짝 들이밀고 자 도 되겠느냐고 요청했다. 상인이 허락하니 낙타는 곧 목을 들 이밀며 허락을 요청했다. 낙타는 점점 앞발을 들이밀고 나중 에는 몸통까지 들이밀더니 급기야는 안이 좁다며 주인더러 밖에 나가 잘 것을 요청했다. 상인은 화가 나서 낙타를 밖으로 내쫓았다. 자신의 본분을 잘 인식하고 있는 사람이라면 이처 럼 무리한 요구에까지 이르지는 않았을 것이다.

그러나 감당키 어려운 상황 속에서는 자신을 지탱하던 힘 의 균형이 무너지고 점차 유아적 단계의 자기애적 전지전능 감과 과대적 환상 상태로까지 이르도록 유도될 수 있다. 퇴 행이 심해지면 자아의 경계 및 분별의식이 마비되고 현실감 을 상실한다. 낙타는 추위라는 불쾌한 상태에서 도피하기 위 해 자신이 낙타라는 사실도 잊어버리고 인간처럼 행동하다 망신을 당한 것이다. 이와 비슷한 예는 불교우화에도 나온 다. 부처를 등에 태우고 가던 당나귀가 부처를 향해 예를 올 리는 사람들을 보고 자신에게 절을 하는 것으로 오인하여 너 무 기분이 우쭐한 나머지 소리를 지르다가 그만 부처를 떨어 트리고 말았다는 우화가 있다. 여기서 나귀는 고달픈 노역에 서 도피하기 위한 퇴행적 방어로 자신을 부처로 착각한 셈이 니 추위를 피하기 위해 자신이 사람인 줄 착각한 낙타와 유사 하다.

\section{투사(Projection)}

투사는 가장 원초적 단계의 방어기제에 속한다. 자신의 내 면에서 받아들일 수 없는 생각이나 감정, 충동 등을 외부의 대상으로 투사함으로써 그러한 속성들이 자신에 속한 것이 아니라 외부 대상의 특성인 양 믿어버리는 것이다. 사람들은 누구나 자신의 약점이나 실수를 솔직하게 인정하기 어려운 법이다. 따라서 항상 남의 탓으로 돌리고 싶은 유혹을 받기 쉽다. 우리 속담에 '물에 빠진 장님 개천 나무란다.' 또는 '잘 되면 내 탓, 못 되면 조상 탓’ 등의 말도 있지만 이 모두가 투 사 심리를 나타내는 것이다.

이솝의 우화「늑대와 학」에서 양을 잡아먹다 목에 뼈가 걸 려 쩔쩔매던 늑대가 지나가던 학에게 사정하며 목에 걸린 뼈를 뽑아주면 톡톡히 사례할 것을 약속했다. 학이 긴 부리로 뼈를 뽑아주니 인사도 없이 돌아서는 늑대를 불러 세워 약속 을 지킬 것을 부탁했다. 늑대는 오히려 화를 벌컥 내며 “사례는 네가 해야지, 내 입속에 부리를 넣고도 무사했으니 말이지.” 하 며 사라졌다. '물에 빠진 장님 건져주니 내 보따리 내놓으라 한다'는 우리 속담과 비슷한 이야기로 투사의 기제를 보여준 다. 타인의 도움을 받는다는 사실이 자신의 자존심에 허락지 않기 때문에 자신의 결함을 상대에게 뒤집어 쓰워 오히려 자 신이 상대에게 도움을 준 것으로 억지를 부리는 것이다.

$\ulcorner$ 재판소의 처마 밑」에서는 영리한 제비 한 쌍이 재판소의 처마 밑에 집을 짓고 새끼를 낳았다. 사람들의 억울한 일을 풀어주는 곳이니 가장 안전한 장소라고 판단했기 때문이다. 그러나 어느 날 먹이를 물고 돌아와 보니 새끼들이 모두 사 라져버렸다. 이웃에 사는 제비들이 알려주기를 뱀이 나타나 다 잡아먹었다는 것이다. 엄마 제비는 슬피 울며 새끼를 잃 은 것도 억울하지만 억울한 사연을 도와주는 재판소 처마 밑 에서 이런 일을 당했다는 게 더욱 억울하고 그래서 재판소가 원망스럽다고 말했다. 여기서 엄마 제비는 자신의 잘못을 재 판소에 투사함으로써 자신의 죄책감을 덜어보려 한 것이다.

\section{부정(Denial)}

부정은 의식에서 도저히 받아들일 수 없는 내용의 존재 자체를 마치 존재하지 않는 것처럼 의식하는 매우 원시적인 단계의 방어기제이다. 중병에 걸린 환자가 새로운 사업을 구 상한다든가, 죽은 아기의 시신을 매장하기 거부하는 엄마의 심리에서 이러한 방어기제를 볼 수 있다. 부정의 기제를 사 용하는 알코올 중독자는 자신의 건강에는 이상이 없다며 간 기능 검사를 거부하는 수가 많은데 이와 마찬가지로 치매에 걸린 노인이 홀로 해외여행을 가야 한다며 고집부리는 경우 도 자신의 상태를 부정하는 것이 된다.

「박쥐」의 이야기는 전형적인 부정의 기제를 보여준다. 날 
짐승과 들짐승 간에 싸움이 벌어진 결과 들짐승 쪽이 이길 듯 하자 박쥐는 날개를 접고 자신이 들짐승이라고 주장해서 무 사했다. 그러나 날짐승 쪽이 우세해지자 다시 자신은 날짐승 이라고 우기며 그들 틈에 끼어 싸웠다. 나중에 평화가 찾아오 면서 양측은 박쥐의 이중적인 처신을 알게 되고 결국 박쥐는 양쪽에서 쫓겨나 어두운 동굴 속에 숨어 살 수밖에 없었다.

「곰과 두 친구」에서는 두 친구가 길을 가다 곰을 만났는데 한 친구는 그대로 길에 누워 죽은 척 하니 곰이 냄새를 맡다 가 죽은 줄 알고 그냥 가버렸다. 나무 위로 올라가 숨어있던 친구가 내려와 묻기를 아까 곰이 자네 귀에 대고 뭐라고 속 삭이더냐고 묻자, 위기를 모면한 친구가 말하기를, "위험에 처한 친구를 버리고 도망가는 친구는 참된 친구가 아니라고 말하더군."이라고 말했다. 어려울 때일수록 서로 돕는 친구 가 참된 친구임을 말해주는 우화이지만 위기에 닥쳤을 때 죽 은 척하는 행동은 일종의 부정을 가리킨다. 앞에서 언급한 타 조 기제도 일종의 부정을 동원한 방어기제라 할 수 있다.

「개미와 베짱이」도 유명한 이야기다. 게으름에 대한 대가 가 무엇인지 그리고 노동의 중요성을 강조한 내용이지만 자 신에게 곧 들이닥칠 위기와 고난을 인정하지 않고 빈둥거리 며 놀기만 한 베짱이는 자신의 현실을 부정한 것이다. 「이리 의 그림자」는 길게 늘어진 자신의 그림자를 보고 자신이야 말로 동물 가운데 가장 키가 크다고 착각한 이리가 사자를 만나 큰소리치다가 혼난다는 이야기로 이는 자신의 처지를 부정한 결과에서 비롯된 것이다. 열등감이 지나치면 자신의 결함을 부정하고 그 대신 스스로 과대적인 망상이나 착각에 빠지기 쉽다는 점을 나타내는 이야기다.

「제비와 삼씨에서도 이와 유사한 이야기를 전한다. 새들 이 곡식을 파먹어서 큰 피해를 입은 농부가 궁리 끝에 이번 에는 밭에 삼씨를 심었다. 눈치 빠른 제비가 다른 새들에게 이를 알려주며 새싹이 돋기 전에 씨앗을 먹어치워야 한다고 말해주었지만 새들은 제비의 충고를 무시했다. 삼이 무럭무 럭 자라나자 농부는 삼 줄기를 벗겨 그물을 만들고 그것으 로 새들을 모조리 잡아버렸다. 자신에게 들이닥칠 위험을 스 스로 인정하지 않고 부정한 결과 위기를 자초한 것이다.

$\ulcorner$ 팔려가는 나귀」에서 아버지와 아들이 나귀를 팔려고 시장 에 가기 위해 길을 떠났다. 나귀를 끌고 가는 부자를 보고 사 람들이 어째서 나귀를 타고 가지 않는지 모르겠다고 말했다. 그 말을 듣고 아버지는 얼른 아들을 나귀에 태우고 갔다. 그 러자 지나가던 노인이 그 모습을 보고 요즘 젊은 애들은 아 비를 걷게 하고 정말 예의가 없다며 비웃었다. 아버지는 얼 른 아들을 내리게 하고 자신이 나귀 등에 올라타고 길을 갔 다. 그런데 이번에는 지나가던 사람들이 비정한 아비라고 흥 을 봤다. 그러자 아버지는 아들을 함께 태우고 길을 가는데,
한 사람이 나귀가 너무 불쌍하다고 말했다. 결국 부자는 나 귀의 네 다리를 묶어서 장대에 메고 갔으나 거꾸로 매달려 가던 나귀가 화가 나서 발버둥치는 바람에 다리 밑으로 떨 어지고 말았다. 도와주지는 않으면서 남의 흥이나 보는 사람 들도 문제지만 줏대 없이 타인의 말에 이리저리 흔들리는 모습은 자신의 주관적 판단을 부정하는 것이라 할 수 있다.

\section{합리화(Rationalization)}

합리화는 무의식적 동기에서 나온 행동의 결과를 그럴듯 한 이유를 내세워 스스로를 위안하는 방어기제이다. 「여우와 포도」는 소위 '신포도 기제'로 유명한 일화다. 길을 가다 목이 마른 여우가 포도나무를 발견했다. 목을 축이려고 포도를 따 먹으려 했지만 뛰어 오르면 오를수록 힘이 빠져 결국 포기하 고 돌아서며 “저 포도는 시어서 못 먹겠군."이라고 중얼거린 다는 내용인데, 이는 합리화의 대표적인 예라 할 수 있다. '닭 잡아먹고 오리발 내밀기'라는 속담도 단순히 상대를 속이기 위한 의식적인 측면보다는 궁지에 몰린 나머지 자기 스스로 를 기만하기 위한 일시적 방편을 동원한 것이기도 하다.

「늑대의 탄식」에서 풀을 뜯고 있던 당나귀에게 늑대가 다 가왔다. 위기에 몰린 당나귀는 꾀를 내어 갑자기 다리를 절 룩거리기 시작했다. 이상하게 생각한 늑대가 그 이유를 물으 니 당나귀는 몹시 아픈 표정을 지으며 발바닥에 가시가 박혔 다고 둘러댔다. 성급히 잡아먹으면 목에 가시가 박힐지도 모 른다고 생각한 늑대는 자기가 대신 가시를 뽑아주겠다고 하 면서 당나귀 발밑을 들여다보았다. 그 순간 당나귀는 뒷발로 늑대의 주둥이를 있는 힘을 다해 걷어찼다. 놀란 늑대는 황 급히 도망가며 “이렇게 된 건 당연하지. 우리 아버지는 먹이 를 잡는 법만 가르쳤지 발에 박힌 가시를 빼는 방법은 가르 쳐주지 않았거든."이라며 투덜거렸다. 이런 태도 역시 합리 화의 기제를 나타낸 것이다.

$\ulcorner$ 말 많은 의사」에 나오는 아주 말이 많은 의사도 합리화의 전형이다. 그가 치료하던 환자가 결국 병이 낫지 않고 죽었 다. 장례식에 찾아온 의사에게 사람들이 그 환자가 왜 죽었 는지 과연 불치병이었는지에 대해 물었다. 의사는 자신 있게 말하기를 고칠 방법은 얼마든지 있었으며 그가 술을 끊고 꿀 을 먹었으면 죽지는 않았을 거라고 대답했다. 한 사람이 나서 서 의사에게 반문했다. "이제 와서 그런 말씀을 하시면 무슨 소용이 있습니까? 그가 죽기 전에 그런 말을 하셨어야지.” 이 와 같은 상황에 직면할 정도로 합리화가 사용된 것이다.

$\ulcorner$ 대머리」이야기에 나오는 주인공의 합리화는 더욱 그럴 듯하다. 자신의 대머리 때문에 항상 부끄러움을 느낀 사람이 고민 끝에 가발을 구해 쓰고 여행을 떠났다. 그런데 바람이 불어닥쳐 가발을 날려버리자 사람들이 보고 마구 웃었다. 그 
는 떨어진 가발을 주워들며 말했다. "웃지들 마시오. 내 것도 아닌 머리털이 바람에 날렸다고 뭐가 그리도 이상합니까? 오 히려 자기 머리털을 떼어버린 사람들이 더 이상하지요." 이처 럼 합리화는 그럴듯한 이유를 대며 자신의 심리적 균형을 유 지하고자 하는 것으로 일상생활에서 매우 보편적으로 동원 하는 방어기제에 속한다. '처녀가 애를 낳아도 할 말은 있다', '홧김에 서방질 한다', '핑계 없는 무덤 없다' 등의 속담도 합 리화의 기제를 잘 보여주는 것이다.

\section{전치(Displacement)}

본래의 대상에서 느꼈던 감정을 상대적으로 덜 위험한 대 상으로 옮기는 과정을 전치라고 한다. 화난 감정 때문에 길 가의 돌멩이를 걷어차거나 자위행위로 인한 죄책감을 손 씻 는 행위로 해소하려는 것 등이 전치에 속한다. '종로에서 뺨 맞고 한강 가서 눈 흘긴다'는 속담은 전치의 기제를 의미하 는 것이다.

「게으른 하녀들」에서 수탉이 우는 새벽이면 하녀들을 깨우 는 할머니가 있었다. 귀찮아진 하녀들은 수탉을 없애버리기 로 하고 마침내 그 닭을 죽여 버렸다. 그러나 수탉이 울지 않 자 시간을 알 수 없게 된 할머니는 전보다 심하게 자주 하녀 들을 깨우는 바람에 일이 더욱 고달파지고 말았다. 하녀들은 자신들의 고달픔을 애꽃은 수탉에게 화풀이했다가 오히려 더 큰 화를 입게 된 셈이다.

「개구리와 소년」은 아이들이 장난삼아 던진 돌이 연못 속 의 개구리에게는 생명을 위협하는 일이 될 수도 있다는 점을 비유한 이야기다. 무심코 자신들의 욕구불만을 죄 없는 개구 리에게 분풀이한 것인지도 모르지만 이는 분명 전치의 기제 에 의한 것이다. 이처럼 엉뚱한 곳에다 화풀이 하는 경우로 가장 흔한 예는 기분 나뼌 말을 듣고 길을 가다 홧김에 돌멩 이를 걷어차는 일이다. 지나가던 행인에게 욕을 하면 곤경에 처하지만 돌멩이는 안전하기 때문이다.

「양치기 소년과 늑대」는 전치의 전형적인 예를 보여준다. 양을 몰던 양치기 소년이 갑자기 장난을 치고 싶어 늑대가 나타났다고 소리치자 마을사람들이 몰려왔지만 매번 거짓 임이 드러났다. 그러다 실제로 늑대가 나타나서 구원을 요청 했지만 이번에도 거짓말임에 틀림없다고 생각한 사람들은 코웃음을 치며 꼼짝도 하지 않았다. 결국 소년은 늑대의 밥 이 되고 말았다. 놀 시간도 주지 않고 일만 시키는 부모에 대 한 불만을 직접 표출하지 못하고 대신 보다 소극적인 방법으 로 마을사람들에게 전치시켜 골탕을 먹이려다가 오히려 자 신이 화를 입고 만 것이다.

\section{동일시(Identification)}

자신에게 중요한 인물의 태도나 행동, 생각들을 자신의 일 부로 받아들여 닮는 것을 동일시라고 한다. 동일시의 대상은 부모가 되기 쉬우며 성격 발달과 형성에 중요한 방어기제이 다. 여아들이 소꿉놀이의 일부로 밥을 짓고 반찬을 만드는 장 난을 하는 행위는 엄마를 동일시하는 것이며 남아들이 총이 나 칼로 전쟁놀이에 몰두하는 것은 용감한 아빠를 동일시하 는 것일 수 있다. 정상적인 동일시는 자아발달에 가장 중요한 방어기제에 속하는 것으로 「어미 게와 새끼 게」에서 그런 기제 를 엿볼 수 있다. 어미 게가 새끼 게에게 말했다. "애야, 넌 왜 그렇게 걷니? 똑바로 좀 걸어 보렴." 새끼 게가 대답했다. "엄 마, 어떻게 걷는지 보여주세요. 엄마 따라서 그대로 해 볼게 요." 어미 게는 새끼 앞에서 시범을 보여줬지만, 결국 똑바로 걷지 못하고 말았다. 말로만 할 게 아니라 솔선수범하는 일 이 중요함을 일깨워주는 내용이지만, 부모의 특성을 그대로 따라 모방하려는 아이의 동일시 기제를 잘 드러낸 우화다.

동일시에는 닮아서는 안 될 상대의 특징을 오히려 닮게 되 는 적대적 동일시, 자신을 공격하는 두려운 상대의 특징을 닮게 되는 공격자와의 동일시, 이상적인 인물과의 공생적 관 계를 통하여 상대의 인물이 지니고 있는 힘의 일부를 공유하 려는 병적 동일시, 상대의 입장이 되어 그와 동일한 느낌이 나 생각을 지니게 되는 감정이입적 동일시, 자타의 구분이 불 분명한 유아기에 일어나는 동일시로 외부의 대상을 입으로 삼키듯이 있는 그대로 자신의 내부로 받아들이는 원시적인 형태의 합일화(incorporation), 적어도 자타의 구분이 가능해 진 유아가 외부 대상에 대해 자신이 느끼고 생각하는 부분을 받아들여 자신의 일부로 만드는 함입(introjection) 등, 여러 형태의 동일시가 존재한다.

「황소개구리」이야기는 지나친 자기 자랑이 오히려 화를 자초할 수 있음을 경계한 내용이지만 자기 분수를 모르고 새끼들 앞에서 황소만한 크기로 배를 불리며 자랑해보이려 다 결국 배가 터져 죽고 마는 아빠 개구리의 이야기는 병적 인 동일시 기제를 보여주는 대목이다. `날고 싶은 거북이」도 마찬가지라 할 수 있다. 날아다니는 새를 부러워한 거북이가 독수리의 도움으로 하늘을 날게 되자 자기도 혼자 힘으로 날 수 있다고 고집을 부려 결국 땅에 떨어져 죽고 만다는 이 야기는 무리한 욕심을 부리지 말라는 내용이지만 비현실적 인 동일시의 비극적인 결과를 비유한 것이다.

「춤추는 나귀」에서 주인 앞에서 재롱을 떠는 강아지를 시 기해서 자신도 강아지처럼 춤추며 재롱을 보이다가 매만 얻 어맞고 광에 갇히는 나귀의 모습은 동일시의 기제를 보인 것이다. 「말과 나귀」에서 무거운 짐을 잔뜩 지고 길을 가던 말과 나귀가 있었다. 나귀가 말에게 하소연하며 부탁하기를, 
더 이상 견딜 수 없으니 짐을 분담하자고 제안했으나 말은 들 은 체도 안했다. 결국 도중에 나귀가 쓰러져 버리자 말의 짐 은 두 배로 늘었다. 고통은 함께 나누어야 함을 강조한 우화 지만 타인의 감정을 공유하지 못하는 감정이입적 동일시의 실패를 가리킨 내용이라 할 수 있다.

「나귀의 소원」은 병적 동일시를 나타낸다. 귀뚜라미의 아 름다운 목소리를 부러워한 나귀가 자신도 그렇게 아름다운 목청이 갖고 싶어 귀뚜라미를 찾아가 도대체 무얼 먹고 살 길래 그토록 목소리가 아름다우냐고 물었다. 귀뚜라미는 풀 잎의 이슬 이외에는 다른 아무것도 먹지 않는다고 일러주었 다. 그날부터 나귀는 배고픔을 참으면서 이슬만을 먹고 지내 다 결국에는 몸이 야위어 죽게 되었다. 이는 이상적인 존재 의 능력을 공유하려는 병적 동일시와 유사하다.

「독수리와 까마귀」도 비슷한 이야기다. 양을 낚아채는 독 수리의 솜씨에 감탄한 까마귀가 자기도 독수리처럼 양을 잡 아보겠다고 달려들었다가 양털에 발톱이 감겨 목동에게 붙 잡히고 말았다. 이러한 동일시는 집단적으로도 일어난다. 종 교적 또는 정치적 집회에서 숭배의 대상을 동일시하는 경우 가 그러하다. 강력한 카리스마를 발휘하는 교주나 정치 지도 자를 동일시하여 그 힘을 공유함으로써 자신감을 얻고 스스 로의 자존심을 유지하는 것이다.

\section{반동형성(Reaction formation)}

'때리는 시어미보다 말리는 시누이가 더 밉다'는 우리 속담 처럼 시누이가 말리는 행동은 본심이 아니라는 사실을 얻어 맞는 며느리는 너무도 잘 알고 있는 법이다. 이처럼 반동형 성은 우리의 일상생활에서 흔히 나타나는 방어기전으로 겉 으로 드러난 태도나 행동이 마음속에 감추어진 내용과 전혀 상반된 경우를 말한다. '미운 자식 떡 하나 더 준다'는 속담도 이에 해당된다. 산을 두려워하는 남자가 오히려 험난한 등산 코스를 즐기는 역공포적 행동이나 동물에 대한 혐오감을 지 닌 사람이 동물보호운동에 앞장서는 행위 등도 반동형성에 속한다.

「노인과 죽음의 신」에서 가난에 허덕이던 노인이 한숨을 쉬며 푸념을 늘어놓았다. "이렇게 사느니 차라리 죽는 게 낫 지. 죽음의 신은 나 같은 늙은이 안 잡아가고 어디서 뭐하 나?” 이때 죽음의 신이 나타나 무슨 일로 자기를 불렀느냐고 물었다. 노인은 당황해서 자신의 말을 얼버무리고 말았다. 마 음에도 없는 말을 하면 반드시 후회하게 된다는 점을 강조한 이야기다.

\section{격리(Isolation)}

격리는 고통스러운 기억과 관련된 감정을 의식에서 분리시
키는 과정으로 사실만을 기억할 뿐 관련된 감정은 따로 억압 하기 때문에 그 감정을 느낄 수 없다. 격리의 기제는 감정적 경험을 차단시키기 위한 것이다. 덤덤한 태도로 고통스런 기 억에 대해 회상하는 경우에도 격리의 기제가 동원된 것이다.

격리는 특히 강박적인 성격의 사람에서 더욱 두드러지게 나타난다. 그러나 정도의 차이는 있겠지만 누구라도 감정적 인 고통을 억누르기 위해서는 다른 대안을 찾기 마련이다. 그중에서도 특히 성적인 욕망이나 공격적인 욕구의 무분별 한 표출은 사회적으로도 엄격히 제한하는 수가 많기 때문에, 그러한 욕망을 회피하기 위한 수단으로 일에만 몰두하거나 사고의 영역으로 도피할 수 있다.

「두 항아리」에서 한 집에 오랫동안 함께 살던 도자기와 구 리 항아리가 어느 날 심한 홍수가 나서 집은 물에 잠기고 두 항아리도 함께 물에 떠내려갔다. 구리 항아리가 도자기에 접 근하려하자 도자기는 멀리 도망가며 자기에게 가까이 오지 말라고 소리쳤다. 그러나 결국 나뭇가지에 걸린 도자기가 멈 칫하는 사이 구리 항아리가 흘러 내려와 두 항아리가 부딪쳐 도자기가 산산조각 나고 말았다. 이처럼 사고와 감정은 상호 밀접한 관련을 맺고 있지만 때로는 상호 배타적이기도 하다. 특히 고통스러운 감정일수록 그 괴로움을 잊기 위해 과도한 생각으로 도피할 수 있다. 지나친 예의 및 형식에 사로잡히 는 태도 또한 감정을 회피하는 유용한 수단이 된다.

\section{취소(Undoing)}

무의식적 욕구로 인한 피해를 최소화하기 위해 원상복귀 하려는 행동을 취소라 한다. 땀 흘리며 열심히 설교하는 젊 은 목사에 대해 성적 욕망을 느낀 한 부인이 죄책감을 없애 기 위해 기도 중에 자신의 이마를 손으로 때리는 속죄행위를 보인 것은 취소에 해당된다. 자신의 몸에 스스로 채찍질을 가하는 종교적 의식도 일종의 취소행위라 할 수 있다. 불법 적인 행위로 돈을 번 마피아 두목이 거액의 헌금을 교회에 기부하거나 전쟁에 악용되어 막대한 인명을 살상한 다이너 마이트를 발명하여 거부가 된 노벨이 자신의 전 재산을 기부 해 노벨상 기금을 내놓은 경우도 마찬가지다. 또는 부부싸움 끝에 부인을 때린 남편이 다음날 꽃을 사다 선물하는 행위 도 취소에 해당한다(Lee 2003b).

가장 잘 알려진 이솝 우화 중의 하나인「도시 쥐와 시골 쥐」 는 취소의 기제를 보여주는 내용이다. 서로 사이가 좋은 시골 쥐와 도시 쥐가 있었는데, 시골에서 고생하며 사는 친구가 안 타까워 도시 쥐가 시골 쥐를 도시로 초대해서 풍부한 음식을 제공했다. 하지만 음식을 먹으려 할 때마다 사람들이 드나들 어 쥐구멍으로 도망쳐 숨어야 했다. 결국 아무것도 먹지 못하 고 배가 고파진 시골 쥐는 이렇게 위험한 곳에서 숨어 사느 
니 차라리 시골에서 마음 편하게 살겠다며 도시를 떠났다. 도시의 화려함에 유혹을 느꼈다가 그 위험성을 깨닫게 되자 자신의 욕망을 취소하고 보다 안전한 시골생활로 되돌아간 것이다.

「나그네와 죽」에서 길을 가던 나그네가 잠시 쉬어갈 것을 허락한 주인이 친절을 베풀어 뜨거운 죽 한 그릇을 내주었다. 그러자 나그네는 뜨거워서 못 먹겠다고 하였다. 주인이 식은 죽을 내주자 이번에는 맛이 없어서 못 먹겠다고 하였다. 결국 화가 난 주인은 나그네를 밖으로 내쫓고 말았다. 자신의 욕망 을 실현시키는 순간 즉각적으로 그 욕망을 취소시킨 나그네 의 변덕은 인간의 이율배반적인 상반된 태도를 드러낸다는 점에서 일종의 반동형성과도 관련이 있어 보인다.

「구두쇠」는 타인이 취소의 기제를 동원해 위로해주는 내용 이다. 한 구두쇠가 오랜 기간 땅에 묻어 숨겨둔 황금을 도둑 에게 잃어버렸다. 친구가 그 애기를 듣고 말했다. "어차피 쓰 지도 않을 황금이었으니 아직도 땅에 묻어두었다고 생각하 시구려." 구두쇠의 상실감과 억울한 심정을 취소의 기제를 동원해 원상태로 되돌려 놓는 효과를 발휘한 셈이다.

\section{지성화(Intellectualization)}

지성화는 무의식적 감정과 충동을 경험하지 않기 위해 그 에 관련된 생각만을 하는 것이다. 불교우화에 독화살을 맞은 남자에 대한 이야기가 나온다. 숲에서 누군가가 쏜 독화살에 맞아 목숨이 위태로워진 한 남자가 서둘러 치료받을 생각은 않고 자신을 쏜 사람이 누구인지 그리고 무슨 이유로 그랬 는지 알아내고자 궁리만 하고 있다는 내용이다. 죽음을 목전 에 두고도 부질없는 미망에 사로잡혀 아까운 세월만 허비하 고 있는 무지몽매한 중생들의 모습을 일깨우는 내용이지만, 세속적인 지식과 앎의 덧없음을 깨닫는 일이야말로 곧 자기 내면을 이해하는 전제조건인 동시에 그런 깨달음에 도달하 기 위해서는 지성화의 방어를 깨는 작업이 급선무임을 강조 한 이야기이기도 하다.

지성화뿐만 아니라 합리화가 동반된 예로는 이솝의 우화 「늑대와 개의 전쟁」을 꼽을 수 있다. 늑대와 개들 간에 싸움 이 붙게 되자 개들은 대장을 뽑아 늑대들과 싸울 준비를 했 지만 대장은 전혀 싸울 기미를 보이지 않고 이런저런 핑계만 늘어놓았다. 늑대들은 모습도 똑같고 단합이 잘되며 복종심 이 강하지만 개들은 제각기 출신도 생긴 것도 다르고 게다가 복종심도 없어서 싸워봤자 질 것이 뼌하다는 이유였다. 이처 럼 지성화는 감정적 문제에서 사고의 영역으로 도피함으로 써 자신의 심리적 평형을 나름대로 유지하려는 시도다. 지성 화는 격리만으로도 감정 문제의 억압이 용이하지 못하다고 판단될 경우에 더욱 강화되기 쉬운 기제다.

\section{일반화(Generalization)}

한 개인의 문제를 그가 속한 집단 전체의 문제로 떠넘기는 일은 일종의 책임 회피이긴 하나 그 개인의 심적 부담을 덜어 주는 효과를 발휘한다. 예수는 한 타락한 창녀를 흥분한 사람 들이 돌로 쳐 죽이려 하는 현장에 나서서 그들 앞에 돌 한 개 를 집어 들고 조용히 말씀하셨다. "너희 중에 죄 없는 자 있거 든 나와 이 여인을 돌로 치라.” 예수의 이 한 마디에 모여든 군 중은 서로 눈치를 보며 한두 사람씩 뒤로 물러나 결국 모두 어 디론가 사라지고 말았다. 각자의 양심에 호소한 이 장면은 매 우 극적인 반전이요, 강력한 일반화의 효과라 하겠다. 그러나 이와는 달리 가톨릭에서 주장하는 소위 '내 탓이오' 운동은 이처럼 어떤 개인의 잘못을 병적으로 일반화시키는 작업에 정면으로 맞서는 일이기도 하다.

이솝의 우화 「나귀의 꾀」에서 소금을 싣고 가던 나귀가 실 수로 개울에서 넘어졌다. 물에 녹은 소금 때문에 짐이 가벼 워진다는 사실을 알게 된 나귀는 그 후부터 일부러 넘어지 는 꾀를 내었다. 손해를 본 소금 장수는 화가 나서 소금 대신 에 솜을 잔뜩 실었는데 그 사실을 눈치채지 못한 나귀는 예전 처럼 다시 개울에서 주저앉아 버렸다. 그러나 다시 일어서보 니 예전보다 짐이 더욱 무거워져 걸을 수가 없었다. 한 가지 경험을 전혀 다른 상황에 일반화시켜 적용함으로써 낭패를 당했다는 이야기이다.

「피리 부는 어부는 피리 불기를 매우 좋아하는 어부가 아 름다운 피리소리를 들으면 고기들도 좋아서 육지로 모여들 거라고 생각했지만 아무리 피리를 불어도 한 마리의 고기도 나타나지 않자 할 수 없이 그물을 던지니 그제야 고기들이 걸려서 팔딱거리는 모습을 보고 고기들을 나무랐다는 이야 기다. 여기서 보인 어부의 방어기제는 자기가 좋으면 남들도 모두 좋아할 거라고 믿는 일반화의 기제를 사용한 것이다.

\section{속죄양(Scapegoating)}

집단 전체의 잘못이나 실수를 어느 한 개인에게 그 책임 을 떠넘기는 경우를 말한다. 앞서 인용한 예수의 일화에서 창녀를 돌로 쳐 죽이려 했던 대중들의 행위는 각자의 죄를 한 여성에게 떠넘기려한 속죄양의 기제를 동원한 것이다. 공 산주의사회에서 흔히 이용되는 자아비판 및 인민재판도 일 종의 속죄양 기제를 통하여 집단의 안전을 도모하기 위한 것 이라 할 수 있다(Lee 2003a).

개인적 불행이나 사회적 혼란의 문제를 모두 대통령 책임 으로 돌리는 것도 속죄양 기제의 흔적이다. 이러한 현상은 어떤 집단이나 심지어 가족 내부에서도 일어난다. 집안 전체 에 예기치 못한 큰 불행이 닥쳤을 때, 그러한 화근이 누구 때 문에 벌어진 일이라며 어느 한 사람의 탓으로 돌리는 경우가 
있을 수 있다. 사회적 물의를 일으킨 대형사건이 터질 때마 다 그 책임을 물어 장관을 경질하는 것도 일종의 속죄양 기 제를 통하여 여론을 무마시키려는 행위이다.

이솝 우화 「뱀과 족제비와 쥐」에서 뱀과 족제비가 서로 싸 움을 벌였다. 쥐들은 자신들을 괴롭히기 일쑤인 적들의 싸움 에 신이 나서 우르르 몰려들어 박수를 치며 싸우다 둘 다 죽 어버리라고 응원을 했다. 치열하게 싸우던 뱀과 족제비는 구 경하던 쥐들을 보고는 싸움을 그치고 쥐들을 모두 잡아먹었 다. 쥐들은 뱀과 족제비의 속죄양이 되어 억울한 죽음을 맞 이한 것이다.

\section{분리(Splitting)}

Klein(1932)은 가장 원초적인 유아기 시절에 인간은 이미 분리라는 방어기제를 사용한다고 주장했다. 반면에 분리는 방어기제로 간주할 수 없고 부정과 차이가 없다는 주장도 있 다(Dorpat 1979). 그러나 오늘날에 이르러 분리의 기제는 대 상관계이론에서 결코 빼놓을 수 없는 핵심적인 개념이 되어 버렸다. 가장 원초적 단계의 유아는 모든 사물을 좋고 나쁜 이분법적 구도로 이해한다는 것으로, 다시 말해서 사리분별 력이 부족한 유아들은 자신에게 즐거운 것이냐 아니면 불쾌 한 것이냐, 또는 도움이 되는 것이냐 아니면 해로운 독이냐 등의 이분법적인 방식으로 세상을 판별할 수밖에 없기 때문 에 불쾌하고 해로운 것으로 판단된 내용을 자신의 내부에서 적절히 희석시킬 능력이 없거나 그대로 담아두지 못하는 특 성을 지닌다.

우리 속담에 '달면 삼키고 쓰면 뱉는다’는 말도 있지만, 프 로이트는 이미 1925년에 이에 대한 언급에서 최초의 자아 수용 모드는 삼키는 것이고 최초의 거부는 뱉어내는 것이라 고 지적한 바 있다(Juni 1979). 그러나 이러한 자아 기능이 무 의식적 방어를 의미하는 것인지의 여부는 확실하지 않은 듯 하다. 왜냐하면 프로이트가 말한 자아란 상대적으로 보다 성 숙한 이후의 단계에 형성되는 것이기 때문이다.

이솝 우화 「여우와 두루미」는 상대의 입장을 고려하지 않 는 인간의 이기적인 욕심을 풍자한 가장 대표적인 이야기다. 여우가 두루미를 초대하여 접시에 담은 국을 대접했다. 여우 는 맛있게 먹었지만 두루미는 먹을 수가 없었다. 두루미는 여우를 초대하여 길쭉한 병 속에 담긴 국을 내놓았다. 이번에 는 여우가 아무것도 먹을 수가 없었다. 남에게 한만큼 자신 에게 다시 돌아온다는 교훈이다. 그러나 내게는 좋은 것이 타인에게 나쁠 수도 있다는 점에서 그리고 좋은 것만 취하 고 나쁜 것은 타인에게 투사하고 즐긴다는 점에서 좋고 나 쁜 것의 공존을 허용하지 못하는 분리의 기제를 드러낸다.

$\ulcorner$ 사슴의 탄식」에서는 연못에서 물을 마시던 사슴이 물에
비친 자신의 크고 아름다운 뿔을 보고 몹시 자랑스러웠다. 그런데 자신의 가늘고 긴 다리가 눈에 띄자 기분이 몹시 상 했다. 그때 갑자기 사자가 나타나 사슴은 있는 힘을 다해 달 아났다. 그러다가 뿔이 나뭇가지에 걸려 사자에게 잡히고 말 았다. 사슴은 자신의 생각이 틀렸음을 후회했지만 이미 때는 늦었다. 극단적인 분리의 기제로 인해 비극적인 신세를 자초 한 셈이다.

「외눈박이 사슴」역시 비슷한 내용이다. 한쪽 눈밖에 볼 수 없는 사슴이 바닷가 근처 풀밭에서 풀을 뜯고 있었다. 보이는 눈은 솦을 향하고 안 보이는 눈은 바다를 향하도록 해서 만일 의 사태에 대비했다. 그런데 한 척의 배가 소리 없이 다가와 서 사슴에게 활을 쏘아 쓰러뜨렸다. 숲은 위험하고 바다는 안전하다는 사슴의 이분법적 사고의 분리가 자초한 화였다.

「선과 악」은 이솝의 우화로는 보기 드문 매우 현학적인 내 용을 담고 있는 우화라 하겠다. 이 세상에는 선과 악이 똑같 이 존재하지만 어찌된 일인지 선은 항상 악에게 쫓기며 살 아야만 했다. 힘없는 신세를 한탄한 선들이 신에게 하소연하 며 좋은 대책을 마련해달라고 했다. 신은 말하기를, 선들이 항상 한데 몰려다니기 때문에 악의 눈에 잘 띄는 것이라고 하면서 앞으로는 각자 흩어져 혼자서 행동하라고 주문했다. 그 후로 악은 눈에 띄게 우글대지만 선은 몰래 움직이므로 눈에 잘 띄지 않게 되었다는 것이다. 악에 물든 세상을 빗댄 내용이지만 선악의 이분법적인 분리는 가장 그 역사가 오래 된 인간의 사유방식이기도 하다. '달면 삼키고 쓰면 뱉는다' 는 속담처럼 분리의 기제는 가장 원초적인 방식의 방어기제 에 속하는 것이다.

「외톨이가 된 까마귀」에서 사람들로부터 항상 사랑받는 비 둘기를 몹시 부러워한 까마귀가 자신의 온몸에 흰 칠을 하고 비둘기 떼에 섞여 들어가 지냈다. 아무도 자기를 의심하지 않 고 먹이 걱정 없이 편하게 지내게 된 까마귀는 기분이 너무 좋아서 그만 무심결에 까악까악 소리 내어 울고 말았다. 까마 귀의 정체를 알게 된 비둘기들은 그를 밖으로 내쫓았다. 갈 데가 없어진 까마귀는 다시 옛날의 친구들에게 찾아갔지만 까마귀들은 그의 흰 털을 보고 다시 내쫓고 말았다. 거짓은 어디서도 환영받지 못한다. 이 역시 흑백논리의 이분법적 분 리라는 함정에 빠진 까마귀의 어리석음을 풍자한 이야기다.

\section{행동화(Acting-out)}

행동화는 말 그대로 사고나 감정을 자신도 모르게 행동으 로 드러내는 것이다. 치료에 대한 거부감 때문에 항상 치료 시간을 제대로 지키지 못하고 지각하는 것도 행동화의 일종 이다. 인간의 자아는 동물과 달리 자신의 현실을 고려하여 이러한 행동화를 억압하고 자제하는 노력을 기울인다. 화가 
날 때마다 손부터 나가는 사람도 있지만 대다수의 사람들은 자신의 행동 결과를 미리 예상하고 자신의 감정을 추스르기 마련이다.

그러나 말도 일종의 행동으로 본다면 순간적인 말실수로 화를 자초하는 경우는 우리의 일상사에서 다반사로 있을 수 있다. 따라서 인간만큼 외교적인 수사학이 발달된 경우는 모 든 동물 가운데 매우 이례적인 현상이라 하겠다. 현존하는 인간의 종족 가운데 가장 행동화 경향이 높은 경우는 아마존 유역에 사는 야노마모족을 들 수 있다. 이들 부족은 가장 난 폭하고 폭력적인 집단으로 사소한 말다툼을 하다가도 살인 까지 저지르는 경우가 비일비재하다고 한다.

이솝 우화 가운데 가장 잘 알려진 「외나무다리」에서는 두 마리 염소가 외나무다리 한가운데서 서로 양보하지 않는다 고 밀치고 싸우다가 결국 두 마리 모두 물에 빠져 떠내려갔 다는 내용을 전하고 있다. 자신의 욕심을 내세워 상대를 공 격하려다 오히려 화를 당한 내용으로 양보의 미덕을 강조한 우화라 하겠다. 자신의 이익과 탐욕만을 내세워 행동으로 옮 기는 인간의 어리석음을 빗댄 내용이다.

「황금알을 낳는 닭」역시 욕심을 부리면 결국 그 대가를 톡 톡히 치른다는 교훈을 담고 있는 내용이다. 황금알을 낳는 닭으로 남부럽지 않게 살던 노부부가 욕심이 더욱 생긴 나머 지 그 닭을 잡아 한꺼번에 황금을 구하려다 결국에는 모든 것을 잃어버린다는 이야기다. 하나는 알고 둘을 모르는 것은 항상 행동을 앞세우기 때문이다. 이와는 달리 의식적인 행동 의 필요성을 강조한 「고양이 목에 방울달기」이야기가 있다. 아무리 좋은 계획도 행동으로 옮기지 못하면 쓸모없다는 점 을 강조한 우화로 온갖 탁상공론의 비효율성을 빗댄 내용이 지만 무의식적인 행동화를 의미하는 것은 아니라는 점에서 비교된다.

\section{보상(Compensation)}

자신의 결함을 메우려는 무의식적인 노력으로, '작은 고추 가 맵다라는 속담처럼 인간은 자신도 모르게 스스로의 약점 을 다른 것으로 보완시키려는 시도를 행하기 마련이다. 고대 소설 「박씨전」의 못생긴 며느리처럼 남다른 지혜와 용기로 자신의 약점을 보상함으로써 세상의 인정을 받는 경우는 흔 히 있는 일이다. 서양에서는 멸시 받는 작은 섬 코르시카 출 신의 키 작은 나폴레옹이 세계정복의 야심을 지녔던 경우가 이에 해당된다(Lee 2003b).

이솝의 우화「두 남매」에 나오는 이야기는 보상의 기제를 잘 나타내는 것이다. 두 남매가 있었는데, 어릴 때는 그 모습 이 별 차이가 없었지만 자라면서 아들은 잘생기고 딸은 못 생긴 얼굴을 갖게 되었다. 속상해진 딸이 아버지에게 화를
내며 왜 자기만 못생긴 얼굴로 낳았느냐고 원망했다. 아버지 는 남매에게 부드러운 말로 달래기를, 오빠는 나쁜 성질로 잘생긴 얼굴을 더럽히지 않도록 하고, 동생은 아름다운 마음 씨를 길러서 미운 얼굴이 나타나지 않도록 하면 된다는 것 이었다.

「토끼와 거북이」는 느림보 거북이에 대한 편견이 토끼의 자만심을 가져와 낭패를 당하는 내용이다. 동시에 꾸준한 노 력이 중요함을 강조한 우화이기도 하다. 거북이는 자신의 한 계를 인정하되 결코 도중에서 포기하지 않는 집념을 통하여 보상하고자 했지만 토끼는 자만심에 빠져 그러한 보상의 필 요성을 느끼지 못함으로써 거북이와의 승부에서 지고만 것 이다.

\section{승화(Sublimation)}

프로이트가 문명화에 가장 큰 공헌을 한 것으로 꼽은 방 어기제가 바로 승화다. 특히 인간의 성적인 욕구와 공격성의 승화야말로 인류 문명을 유지하는 가장 강력한 도구가 되기 때문이다. 비극적인 전쟁 대신에 월드컵 축구와 같은 대리전 쟁을 통해서 파국을 막을 수 있는 것도 승화의 기제 덕분이 다. 청소년의 탈선행위를 막기 위해 그들의 폭발적인 열정을 운동이나 건전한 취미활동 및 종교활동을 통하여 해소하는 것도 승화이며, 예술적 창조행위도 근원적인 욕망과 환상의 승화라 볼 수 있다.

이솝의 우화「아버지의 교훈」에서 밤낮으로 싸움질만하는 세 아들을 불러놓고 한 아버지가 그들에게 커다란 나뭇단을 돌아가며 ㄲㄲㄲ어보라 요구했다. 세 아들이 모두 실패하자 묶음 을 셋으로 나누어 각자 꺾어보라고 하였더니 손쉽게 성공했 다. 작은 힘도 뭉치면 큰 힘을 발휘할 수 있음을 가르치는 우 화내용이다. 여기서 형제 간의 이기적인 경쟁심도 힘을 합쳐 좋은 쪽으로 승화시키면 큰 일을 해낼 수 있음을 암시한다.

$\ulcorner$ 개미와 나비」에서 개미가 길을 가다 만난 볼품없는 번데 기 앞에서 자기 자랑을 늘어놓았다. 며칠 후 보니 번데기는 빈껍데기뿐이었다. 그때 아름다운 나비 한 마리가 날아와 다 정스레 말을 걸었다. 개미는 나비가 부러워 자신의 신세 한탄 을 늘어놓았다. 그러나 나비는 개미가 물고 있는 번데기에서 자신이 나왔음을 알려주고는 어디론가 날아가 버렸다. 보기 흥한 번데기에서 아름다운 나비로 변신한 것이 승화다.

\section{이타주의(Altruism)}

남을 돕는 행위는 매우 성숙한 인간적 심성의 발로다. 모 든 인도주의는 이러한 이타주의에 힘입은 결과이다. 물론 반 동형성으로 인해 남을 도울 수도 있지만 다른 점이 있다면 이타주의는 본인 자신이 만족을 느낀다는 점에서 차이가 있 
다. Freud(1936)는 이러한 이타주의 역시 성숙한 방어기제 로 간주했다. 그러나 이는 보다 광범위한 의미로 사용되는 승화기제의 일부라고 보는 것이 나을 것이다.

이솝 우화 「은혜 갚은 개미는 물에 빠진 개미를 구해준 비둘기가 개미의 도움으로 위기를 모면하는 이야기로 누구 에겐가 베푼 작은 친절도 큰 은혜로 다시 되돌아온다는 교 훈을 암시한다. 그러나 조건 없이 남을 돕는 행위도 방어의 일종으로 볼 것인가에 대해서는 논란의 여지가 있다고 본다. 또한 단순한 동정심의 발로이든 아니면 남다른 공감능력의 표현이든 간에 남을 돕는 행위는, 수단 방법을 가리지 않고 타인을 이용하고 착취하는 이기적인 욕망에 물든 현실을 고 려한다면 그 동기야 어찌됐건 바람직한 행위가 아닐 수 없 다. 다만 신경증적 동기에 의해 드러난 이타주의는 그 생명 이 오래가지 못한다는 점에서 주목할 필요가 있다.

\section{고 찰}

인간은 누구나 자신의 심리적 평형을 유지하고 갈등에 휘 말리지 않기 위해 자아의 방어기제를 불가피하게 동원할 수 밖에 없다. 따라서 프로이트의 갈등이론은 방어기제의 실체 를 밝히는 초석이 되었다. 다만 그는 너무 억압에만 치중하 여 모든 노이로제 현상을 규명하려 했으며 또한 리비도설에 강한 집착을 보였기 때문에 보다 정교한 방어기제의 연구에 는 소홀했던 감이 든다.

그럼에도 불구하고 프로이트는 억압 외에도 투사, 퇴행, 반동형성, 격리, 취소 등의 기제들을 언급하였으며, 그의 딸 안나 프로이트는 여기에 부정 및 이타주의 등의 승화를 더 추가하면서 보다 정교한 방어기제의 세분화를 시도하였다 (Freud 1936). 그러나 그녀는 질환과의 관련성을 맺고자 하 는 시도를 하지 않았으며, 이들 기제에 대한 초심리학적 설 명에도 인색하였다. 그럼에도 그 후 방어분석은 정신분석에 서 매우 중요한 치료 작업의 일부가 되었다. Fenichel(1945) 은 자아의 방어를 성공적인 방어와 성공에 실패한 방어로 구분하면서 실패한 방어는 반복, 지속하는 경향이 높다고 하 였다. Horney(1945)는 주로 환경과의 관계 차원에서 신경증 환자의 주된 자아 방어기제를 7가지로 요약하였는데, 맹점 (blind spots), 합리화(rationalization), 회피(elusiveness), 간격 화(compartmentarization), 임의적 정당화(arbitrary rightness), 냉소주의(cynicism)를 언급한 반면에, Klein(1964)은 프로이트가 주목하지 못했던 조기 모자관계에서 유아의 내 면세계에 나타나는 분리와 투사적 동일시를 추가하였다. 그 녀가 주장한 가장 원초적 단계의 방어기제들은 그 후 경계성 환자군을 이해하는 데 중심적인 역할을 맡게 되었다(Kern- berg 1967). Vaillant(1986)는 자아심리학의 관점에서 광범위 한 방어기제들의 분류체계를 확립시키고자 노력하였지만, 이와는 조금 다른 관점에서 Modell(1975)은 나르시시즘도 정 동에 대항하는 일종의 방어기제로 간주한 반면에, Kohut (1971)는 수직적 분리(부정)와 수평적 분리(억압)를 언급하였 다. 또한 Bibring 등(1961)은 무려 39가지의 방어기제를 언 급함으로써 가장 광범위한 연구 업적을 남겼다. 이처럼 방어 개념의 확대로 인해 오히려 새로운 문제를 불러일으키는 결 과를 낳기도 했다. 그것은 스트레스 개념이 무한대로 확장되 면서 인간의 삶에서 스트레스 아닌 것이 없게 된 경우와 비슷 하다. 모든 것이 방어로 설명되다 보면 이론적 설득력이 그만 큼 힘을 잃고 그 효용가치가 떨어지기 때문이다. 그러한 현상 은 이미 프로이트가 자아의 무의식적 방어개념을 언급한 직 후부터 나타나기 시작했다는 지적도 있다(Sperling 1958).

그런 점에서 Laplanche와 Pontalis(1973)가 방어 개념의 무모한 확장에 대한 우려를 표시한 것은 학문적으로 매우 정당한 태도라 할 수 있다. 그럼에도 다양한 방어기제에 관 한 연구는 학문 그 자체로서는 정당하다. 비록 인간 존재를 방어체계의 집합체로 전락시킨다는 비판적 시각도 있지만 양자물리학자가 미립자를 연구한다고 해서 인간 존재를 단 순한 원자의 집합체로만 인식하는 것은 아니듯이 분석학자 가 방어기제를 심도 있게 연구한다고 해서 인간 전체를 방 어의 개념으로만 인식하는 것은 아니다. 지나친 사고의 비약 이며 왜곡일 뿐이다. 다만 Brenner(1982)도 주장한 바 있듯 이, 방어란 특정한 타협 형성에서 나타나는 것일 뿐이며, 분 석을 통하여 사라지는 것도 아니고 점진적으로 정상화되거 나 성숙해지는 것도 아니라는 사실을 인식할 필요가 있다. 이솝의 우화에서 그 실체가 분명하게 드러나지 않는 방어기 제로는 전환, 해리, 신체화, 함입, 내재화, 상징화, 간격화 등 을 들 수 있다. 이는 물론 시대적, 문화적 차이에 기인한 결 과일 수도 있겠으나 히스테리 현상에 대한 의학적 인식이 최초로 시도되기 시작한 것이 히포크라테스의 활동 시기와 일치한다고 볼 때, 그보다 200년이나 앞선 시기에 활동했던 이솝이었다는 점을 고려한다면 충분히 이해할 수 있는 부분 이라 하겠다.

물론 그보다 훨씬 후대에 활동했던 예수의 행적을 통하여 다양한 유형의 전환 및 신체화 경향이 존재했음을 보고한 연구도 있지만(Sohn 1999), 일반적으로는 기독교사회의 전 통에 따라 마귀가 역사한 것으로 이해하는 수가 많았다. 따 라서 중세 마녀사냥에 희생된 수많은 여성들 가운데에는 적 지 않은 수의 여성들이 전환 및 해리 등의 성향을 보였다는 이유만으로 희생당했을 가능성도 부인할 수 없을 것이다.

Abse(1987)는 프로이트 이전에도 히스테리성 전환 및 해 
리현상에 대한 기록들이 있었음을 지적하고 그와 유사한 형 태의 현상들은 세계 어느 곳에서나 여전히 발견된다고 하였 다. Pipineli-Pontamianou(1982)는 자아방어의 관점에서 본 다면 프로이트가 인용한 오이디푸스 신화보다는 오히려 히 폴리투스 신화가 더욱 적절할 것이라 주장하였다. 왜냐하면 근친상간적 애증의 교차 및 부왕의 징벌 등이 오이디푸스 신 화에서보다 매우 극적으로 드러나 있기 때문이라는 것이다.

물론 이솝은 자아 방어개념에 대해 전혀 알 리가 없었겠 지만, 이번 연구에서 이솝의 우화가 수많은 방어기제를 잘 반영하고 있음을 알 수 있었다. 이는 방어기제란 지상에 존 재하지도 않는 개념을 새로 창조해낸 것이 아니라 인간의 심리적 현상과 행동 양상을 통하여 추론할 수 있는 매우 유 용한 심리적 장치를 프로이트가 개념적으로 규명한 것이기 때문이다. 인간이 자신의 심리적 평형을 유지하기 위해 무의 식적으로 심리적 방어기제를 동원한 것은 정신분석적 개념 이전부터 존재하고 있었던 것임을 증명한 것이다.

여기서 예시한 기제들은 이솝의 방대한 이야기 내용을 모 두 참조한 것이 아니기 때문에 부족한 부분도 있을 수 있다. 그러나 보다 면밀히 그의 우화 내용들을 연구한다면 상기 언급한 기제들 외에도 다른 다양한 방어기제들을 추가적으 로 찾아낼 수 있을 것이다. 정신방어기제는 유아기 시절부터 이미 동원되기 시작하는 것이며, 원시부족들도 심리적 위기 상태에서는 스스로를 방어하지 않으면 안 되었을 것이다. 따 라서 자아의 방어기제란 정신발달과정에 필수불가결한 요 인이 될 수밖에 없으며, 동시에 인격의 특성을 좌우하는 매 우 중요한 축을 이루는 부분이기 때문에 시대적 간격을 초 월하는 것이다.

\section{결 론}

위대한 이야기꾼 이솝의 존재는 실로 불가사의한 일이 아 닐 수 없다. 한 개인의 힘으로 그토록 방대한 이야기들을 남 겼다는 사실이 믿어지기 어렵기 때문이다. 때문에 이솝 이야 기는 한 사람의 작품이 아니라 작가 미상의 많은 이야기들 을 한데 모은 것이라는 주장도 있어왔다. 그러나 중요한 것 은 시대의 변화를 초월한 일관된 주제라 할 수 있으며, 수천 년이 지난 오늘날에 와서도 이솝의 이야기는 여전히 그 생명 력을 잃지 않고 오히려 더욱 그 빛을 발한다는 사실에 있다.

이솝은 프로이트보다 시대적으로 무려 2500년 전 사람이 었지만 날카로운 직관력으로 인간심리의 부조리한 측면에 일찌감치 눈뜬 인물이었다. 비천한 노예 신분이었던 만큼 그 에게는 인간의 고통과 모순의 비합리성에 대한 남다른 비판 적 성찰과 안목이 주어졌는지도 모른다. 따라서 그는 주로
동물들의 세계에 빗대어 그러한 심리적 모순들을 우회적으 로 묘사하긴 했지만 매우 예리한 관찰력을 동원하여 인간 심리의 어리석음을 질타한 것이다.

그러나 이솝뿐 아니라 정신분석적 개념을 알기 이전에 살 았던 우리 조상들도 속담, 민담, 설화 등을 통하여 알 수 있 듯이 인간사에서 빚어지는 온갖 심리적 방어기제 등에 대하 여 어렴풋이나마 인식하고 있었음이 분명하다. 따라서 인간 의 다양한 방어기제들이 심리적 갈등이나 고통, 곤경에서 벗 어나기 위한 자아의 고육지책이라는 관점에서 본다면 고대 사회나 현대사회가 크게 달라진 점이 별로 없는 것 같이 보 인다. 인간이라는 존재가 단순한 방어의 집합체가 아니라는 사실은 이솝이나 프로이트 모두 실제 경험을 통하여 잘 인 식하고 있었음에 틀림없다. 두 사람 모두 삶의 고통이 무엇 인지 누구보다 잘 알고 있었으며 그들의 삶에 대한 통찰이 단순한 추론적 성찰에 의존한 결과는 아니었기 때문이다.

따라서 수천 년 전부터 널리 알려져 온 이솝 우화를 통해 오늘날 우리가 익히 알고 있는 다양한 방어기제를 엿볼 수 있다는 점을 이번 연구에서 알 수 있었다. 이는 프로이트가 탐색한 방어기제가 인간 본성을 잘 반영하고 있다는 점뿐만 아니라 사회문화적 특성, 시대적 변화를 넘어선 보편적 심리 의 작동 기제임을 제시하는 증거의 하나라고 결론을 내릴 수 있다.

\section{Conflicts of Interest}

The author has no financial conflicts of interest.

\section{REFERENCES}

Abse DW. Hysteria and related mental disorders: an approach to psychological medicine. Bristol: Wright;1987.

Bibring GL, Dwyer TF, Huntington DS, Valenstein AF. A study of the psychological processes in pregnancy and of the earliest mother-child relationship. Psychoanal Study Child 1961;16:9-24.

Brenner C. The mind in conflict. New York, NY: International Universities Press; 1982

Dorpat TL. Is splitting a defense? Int Rev Psychoanal 1979;6:105-113.

Fenichel $\mathbf{O}$. The psychoanalytic theory of neurosis. New York, NY: W. W. Norton \& Company; 1945.

Freud A. The ego and the mechanisms of defense. New York, NY: International Universities Press; 1936.

Freud S. The neuro-psychoses of defence. SE 3. London: Hogarth Press; 1894. p.41-68.

Freud S. Remembering, repeating and working-through. SE 12. London: Hogarth Press;1914. p.145-156.

Freud S. Inhibitions, symptoms and anxiety. SE 20. London: Hogarth Press;1925. p.77-176.

Horney K. Our inner conflicts. New York, NY: W. W. Norton \& Company; 1945 .

Juni S. Theoretical foundations of projection as a defense mechanism. Int Rev Psychoanal 1979;6:115-130.

Keller JE, Keating LC. Aesop's fables: with a life of Aesop. Lexington, KY: University Press of Kentucky; 1993.

Kernberg O. Borderline personality organization. J Am Psychoanal As- 
soc 1967;15:641-685.

Klein M. Contributions to psychoanalysis, 1921-1945. New York, NY: McGraw-Hill;1964.

Klein M. The psychoanalysis of children. London: Hogarth Press;1932.

Kohut $\mathbf{H}$. The analysis of the self. New York, NY: International Universities Press;1971.

Laplanche J, Pontalis JB. The language of psychoanalysis. London: Hogarth Press; 1973.

Lee BW. Interpretation and self-criticism. Psychoanal 2003a;14:167-176.

Lee BY. Psychiatric dictionary. Seoul: Iljogak;1997.

Lee MS. Invitation to psychoanalysis. Seoul: IU;2003b.

Lobban R. "Aesop." Historical dictionary of ancient and medieval Nubia. Lanham, MD: Scarecrow Press;2004.
Modell AH. A narcissistic defence against affects and the illusion of selfsufficiency. Int J Psychoanal 1975;56:275-282.

Pipineli-Pontamianou A. On ego defenses. Psychoanal Study Child 1982; 37:421-432.

Reich W. Character analysis. New York, NY: Orgone Institute Press; 1933.

Sohn JW. Psychotherapeutic factors of jesus' healing in the new testament. Psychoanal 1999;10:243-261.

Sperling SJ. On denial and the essential nature of defense. Int J Psychoanal 1958;39:25-38.

Vaillant GE. Empirical studies of ego mechanisms of defense. Washington, DC: American Psychiatric Press; 1986. 